\title{
Adenosine - A Physiological Regulator and a Distress Signal
}

\author{
Bertil B. Fredholm*
}

Department of Physiology and Pharmacology, Karolinska Institutet, S-171 77 Stockholm, Sweden

\begin{abstract}
The present brief review argues the case that adenosine can be both a distress signal and a physiological regulator. A key factor in determining which of these possibilities pertain is related to the number of receptors expressed. As the signaling from the adenosine receptor to the functional response generally involves amplification, we have a situation involving so called spare receptors. This has the consequence that alterations in the receptor number lead to shifts in the potency of the endogenous agonist rather than a shift in the maximum response elicited. The roles of adenosine are studied by antagonists and/or animals (mostly mice) with targeted deletions of receptors or enzymes involved in adenosine metabolism. Whereas, adaptive changes in the genetically modified mice can occur for the physiologically important effects, such adaptive changes are less likely to occur for the situations when adenosine acts as a distress signal.
\end{abstract}

Keywords: Adenosine receptors, ATP, genetically modified mice, receptor reserve.

There are four evolutionarily well conserved receptors for adenosine denoted $A_{1}, A_{2 A}, A_{2 N B}$ and $A_{3}$ [1]. They form a distinct group among the so called $\mathrm{G}$ protein-coupled receptors. The $\mathrm{A}_{1}$ and $\mathrm{A}_{3}$ receptors are predominantly coupling to members of the $G_{i}$ family of $G$ proteins; the $A_{2 A}$ and $A_{2 B}$ receptors predominantly couple to members of the $\mathrm{G}_{\mathrm{s}}$ family of $\mathrm{G}$ proteins. Under some circumstances, especially when over expressed, these receptors can also couple to members of the $\mathrm{G}_{\mathrm{q}}$ and $\mathrm{G}_{12}$ families of proteins [2].

The potency of adenosine at these receptors is obviously determined by the affinity of the endogenous ligand (adenosine) to the different receptors. Unfortunately, it proves very difficult to determine this affinity. The reason is that adenosine is rapidly metabolized and formed in biological preparations including membrane preparations. Therefore, if metabolism of adenosine is prevented, endogenous adenosine accumulates to confound the measurements. Especially to receptors coupling to $G_{i}$ proteins this endogenous adenosine can be cryptically bound and also influence the apparent $B_{\max }$ values [3, 4]. For this reason, we do not have reliable data on the comparative affinity of the endogenous agonist at the four adenosine receptors.

We must therefore, rely on the determination of the potency of adenosine in functional assays. This introduces another important confounding factor: potency of the agonist is markedly influenced by the receptor number [5-8]. The reason for this is that adenosine receptors are generally coupled via several amplification steps to the final response, and they, therefore exhibit the behavior described by pharmacologists as "spare receptors". In such systems, alterations in the receptor number are manifested by parallel shifts in the dose response curve, not as alterations in the maximal response. Therefore, it is important to compare potencies between receptors at comparative receptor densities. When this

*Address correspondence to this author at the Department of Physiology and Pharmacology, Karolinska Institutet, SE-171 77 Stockholm, Sweden; Tel: +46 85248 7939; Fax: +4683412 80;

E-mail: Bertil.Fredholm@fyfa.ki.se is done it is observed that adenosine is equipotent at $A_{1}, A_{2 A}$ and $\mathrm{A}_{3}$ receptors, but is some 50 times less potent at $\mathrm{A}_{2 \mathrm{~B}}$ receptors if alterations in cAMP are recorded [9]. If, by contrast, we instead examine the ability to activate MAP kinase (which all the receptors do), adenosine is equipotent at all of them $[10,11]$. Thus, the potency of endogenous adenosine depends on the receptor number, and on the type of response measured. Furthermore, there is no really good reason to divide the receptors into high affinity and low affinity receptors as is sometimes done.

\section{REGULATION OF ADENOSINE LEVELS}

Adenosine is at a crossroad between different metabolic pathways. Hence, there will always be a finite intracellular concentration of adenosine. Furthermore, most, if not all, cells possess equilibrative adenosine transporters $[12,13]$. Therefore, there will, by necessity, be also finite levels of adenosine in the extracellular space, even under the most basal conditions. This basal level has been estimated to be in the range of 30-200 $\mathrm{nM}$ [14]. From this baseline level, adenosine can increase substantially via several mechanisms. The equilibrative transporters (ENT 1-4) are usually sensitive to inhibition by drugs, such as dipyridamole and dilazep, but the ENT4 subtype present in e.g. heart is much less sensitive to such blockade [15]. The blockers can raise levels of adenosine in such cells that are net producers, and at the same time raise extracellular adenosine concentrations, which explains much of their therapeutic interest.

There are two principally different ways in which adenosine levels may be increased - formation intracellularly and export via transporters, and formation in the extracellular space from adenine nucleotides released from cells. The earlier literature on adenosine emphasized the former possibility $[16,17]$. Adenosine was formed intracellularly whenever there was a discrepancy between the rates of ATP synthesis and ATP utilization. Thus, adenosine would be formed the when work load was markedly enhanced or when the supply of metabolizable energy (viz. oxygen and glucose) is limiting as would be the case inter alia in ischemia. 
More recently, interest has centered on the role of regulated release of ATP as an important source of extracellular adenosine. Whereas the focus here was initially on the release of ATP as a neurotransmitter, stored together with other transmitters [18], several other mechanisms have now moved to the foreground. One major reason for this is that, the classical transmitter vesicles are rather small, and since they contain at least an order of magnitude less ATP than classical transmitter the amounts released will be quite limited especially over any distance [19]. Another reason is that, ATP is released from many cells that do not release transmitters. Among the mechanisms to be considered are: 1) release from cells with damage to the cell membrane e.g. in necrotic cell death, 2) release from large storage vesicles containing hormones, 3) via connexin/pannexin "hemichannels", 4) from transport vesicles delivering proteins to the cell membrane, and 5) from a subset of lysosomes. It is well known that ATP is released from many cells, where cell membranes subjected to stretch [20], perhaps via one of the above mentioned mechanisms.

Release from cells with damaged cell membranes could provide large increases in extracellular purine levels since ATP levels in cells are typically 3-5 $\mathrm{mM}$ and extracellular adenosine levels 30-200 nM. Release from large storage vesicles that also contain hormones or enzymes is potentially a more important source than the transmitter storing vesicles, since they are typically much larger and hence the total amount of ATP is higher. For example, the evidence that takes place in pancreatic islets is quite convincing [21]. By contrast, the evidence for an important kiss-and-run release from synapses is more controversial [22], even though stronger evidence is now emerging [23].

Connexins form gap junctions. Clearly that much cellcell contact is mediated via gap-junctions formed by connexins (or connexin like proteins). The cells that express connexins will sometimes express them on such a position of the cell membrane, where they cannot contact a connexins on another cell. This constitutes a connexins "hemichannel" [24]. Such hemichannels have been proposed as the channel that causes the release of ATP e.g. in astrocytes [24], and an important role in early development has been postulated [25]. It is attractive to consider the same molecule as mediator of two separate modes of cell-cell communication: gap junction contact and ATP-mediated communication [24]. Within the context of the present review, a role of these channels in endothelial cells, cardiac cells [26], smooth muscle cells and cells of the immune system [27] is particularly interesting to consider. It is potentially important that connexins have been suggested to play a critically important role in preconditioning [28], as has adenosine (see below).

The process whereby newly synthesized membrane proteins are inserted in the cell membrane involves fusion of intracellular vesicles with the plasma membrane, and in the process nucleotides can be released [29]. It has also been shown, that lysosomes contain abundant ATP, (perhaps because of their low $\mathrm{pH}$ ) and that they release ATP via partial and full exocytosis, and that this process can be increased by relevant stimuli, such as metabolic deprivation or extracellular ATP [30]. The relative importance of these different mechanisms probably differs depending on the cell type and the stimulus.
Once ATP (or ADP) is released, the phosphate groups of extracellular ATP are rapidly split off by ecto-enzymes working in concert, first via nucleoside triphosphate diphosphohydrolases (NTDPases) similar to CD39 [31], followed by hydrolysis via ecto-5'-nucleotidase, CD73 [32]. Knockouts of these enzymes have revealed their importance in different organs and situations.

\section{PHYSIOLOGICAL VERSUS PATHOPHYSIOLOGI- CAL ROLES}

Several studies estimate the resting extracellular levels of adenosine to be in the range $20-300 \mathrm{nM}$ [14, 33-38], and the levels can rise to the low micromolar range in extreme physiological conditions, such as strenuous exercise or subsistence at high altitude, and hence low ambient oxygen [14, $33,34,38]$. In ischemic areas or after massive tissue trauma leading to cell death by necrosis levels can increase to perhaps $30 \mu \mathrm{M}[36,38,39]$.

If these data are related to the estimated potency of adenosine receptors we arrive at a picture like that illustrated in Fig. (1). One can see that, in places where the receptors are very abundant, there will be a physiological role of adenosine and in places where receptors are fewer may only be activated under extreme or pathological circumstances.

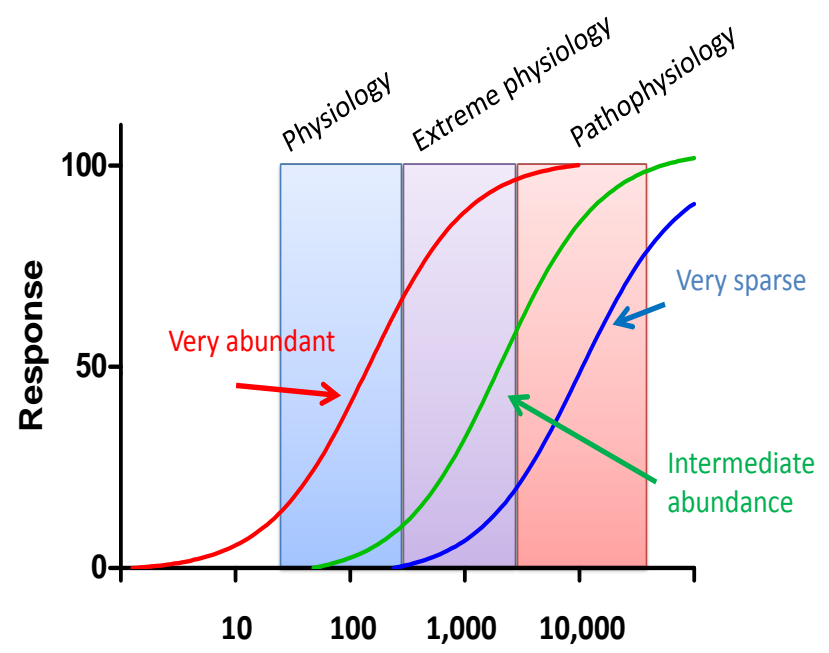

Fig. (1). Schematic illustration of the relationship between adenosine concentration and the effect mediated by adenosine receptors when the receptors are very abundant (as for example the $A_{2 A}$ receptors on striatopallidal neurons where levels are well above 100 , 000 receptors per cell), or when they are less abundant (down to a 100 receptors or less per cell). Typical experimental data showing the relationship between receptor number and position of the doseresponse curve are found in references [5-8]. This relationship is then superimposed on data on the levels of adenosine (in $\mathrm{nM}$ ) in tissue fluids under different circumstances. This is also based on actual measurements referred to in one of the several studies using microdialysis referred to in this review.

There have been many studies examining the roles of the adenosine receptors in different biological processes. Some of the key results are summarized in Table $\mathbf{1}$. 
Table 1. Selected Effects Mediated by Adenosine via the Four Adenosine Receptors. For this Table I have Predominantly Used Data from Genetically Modified Organisms. The Column Labelled "Adaptation" Refers to Known (or Presumed/Possible?) adaptive Reactions Obvious in the Phenotype of Knock-Out Animals

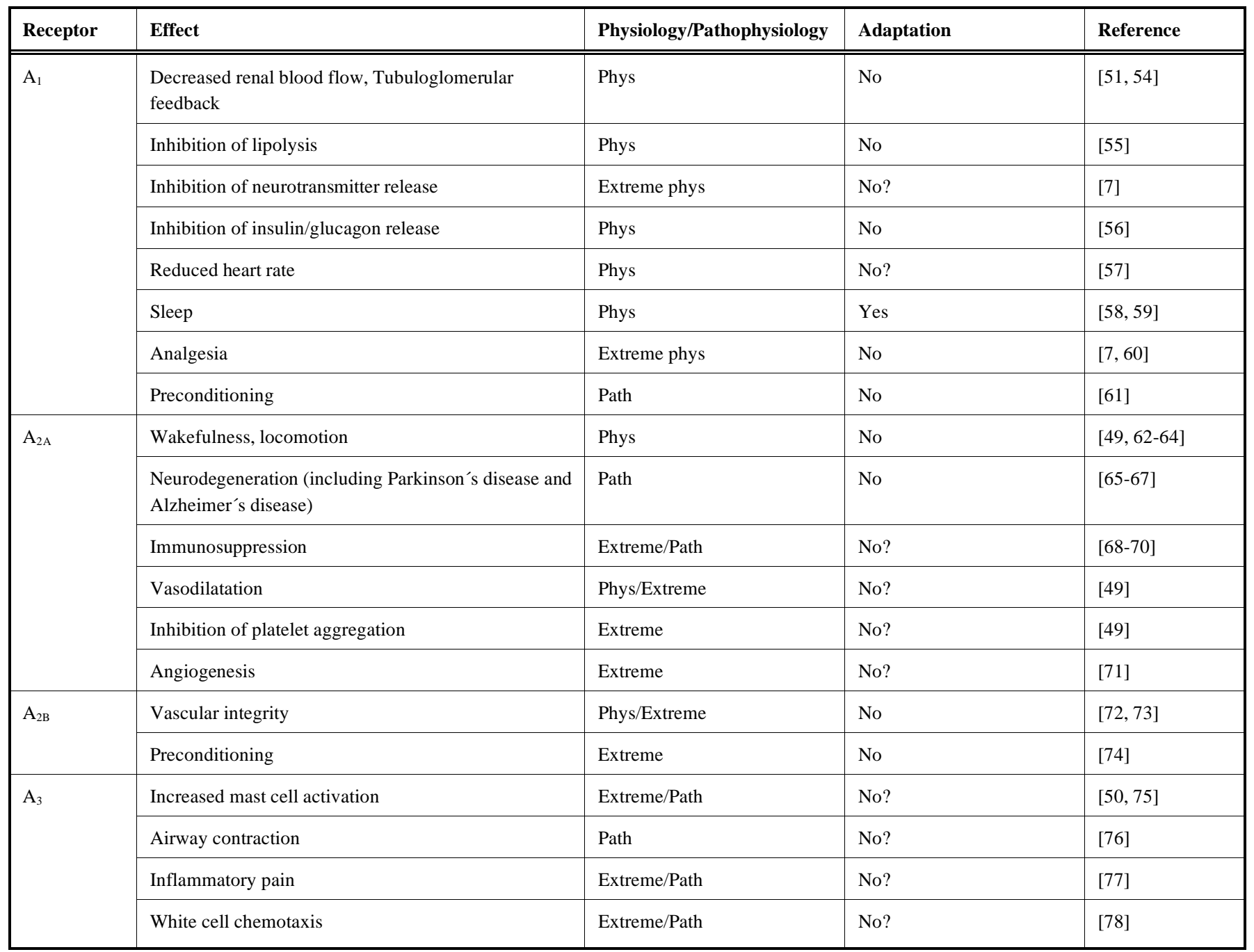

\section{HOW TO STUDY THE ROLES OF ADENOSINE RECEPTORS}

The roles of the receptors can be studied either by pharmacological means or altering the expression of the receptor protein. For a long time, the only available approach was the pharmacological one: Using agonists one could determine which type of responses might be elicited and using antagonists which of these, in fact, did occur and under which circumstances. Over the years, several very useful pharmacological tools have been developed as presented in several reviews [1, 40-47]. Nevertheless, their specificity is rarely complete and most of the selective compounds have physicochemical properties that limit their usefulness, especially for in vivo studies. Of particular interest is of course caffeine, the most widely used of all psychoactive drugs, that in habitually used doses blocks the three first adenosine receptors, and this accounts for many of its effects [48].

A more recent alternative is the use of genetically modified organisms [7, 49-52] and/or targeting with siRNA [53]. In many instances, the results obtained with drugs and those observed in the genetically modified animals are entirely consistent. However, this is not always the case. One reason is that the drugs may not be as selective as was thought, and indeed the use of genetically modified animals to test the specificity of drugs is becoming a more and more established practice. Another reason for the discrepancy is that drugs rarely achieve a complete blockade of an adenosine receptor for any length of time and complete elimination of a response and partial blockade may have different consequences. A third possibility is that the genetic modification has resulted in major adaptive changes.

There is a common misconception that genetic elimination of one of the adenosine receptors should lead to up regulations of one or more of the other adenosine receptors. There are really few, if any, examples of this type of adaptation. Alternatively, completely different processes may show adaptive changes. However, this also appears to occur only rarely [e.g. 7, 8]. Perhaps one should expect only such processes that are physiologically regulated by an adenosine receptor to be compensated for in a targeted receptor deletion. There is little pressure to induce adaptations of processes that occurs rarely in a life time. Furthermore, not all physiological processes need to or can be compensated for. It is 
therefore, of some interest that I have found very few examples of adaptive compensations the in receptor knock-out mice, but several examples of where possible adaptations have been insufficiently studied (Table 1).

In summary, adenosine receptors are involved in many different processes, both physiological and pathophysiological. The fact that they are doing so many things, not only offering therapeutic opportunities, but also providing limitations for future drug development.

\section{REFERENCES}

[1] Fredholm BB, IJzerman AP, Jacobson KA, Klotz KN, Linden J. International Union of Pharmacology. XXV. Nomenclature and classification of adenosine receptors. Pharmacol Rev 2001; 53(4): 527-52.

[2] Fredholm BB, Arslan G, Halldner L, Kull B, Schulte G, Wasserman W. Structure and function of adenosine receptors and their genes. Naunyn Schmiedebergs Arch Pharmacol 2000; 362(45): 364-74.

[3] Parkinson FE, Fredholm BB. Differential effect of magnesium on receptor-G-protein coupling of adenosine $A_{1}$ and $A_{2}$ receptors: a quantitative autoradiographical study. Mol Neuropharmacol 1992; 1: 179-86.

[4] Parkinson FE, Fredholm BB. Magnesium-dependent enhancement of endogenous agonist binding to A1 adenosine receptors: a complicating factor in quantitative autoradiography. J Neurochem 1992; 58(3): 941-50.

[5] Arslan G, Kontny E, Fredholm BB. Down-regulation of adenosine A2A receptors upon NGF-induced differentiation of PC12 cells. Neuropharmacology 1997; 36(9): 1319-26.

[6] Arslan G, Kull B, Fredholm BB. Signaling via A2A adenosine receptor in four PC12 cell clones. Naunyn-Schmiedebergs Arch Pharmacol 1999; 359(1): 28-32.

[7] Johansson B, Halldner L, Dunwiddie TV et al. Hyperalgesia, anxiety, and decreased hypoxic neuroprotection in mice lacking the adenosine A1 receptor. Proc Natl Acad Sci U S A 2001; 98(16): 9407-12.

[8] Johansson S, Yang J, Lindgren E, Fredholm BB. Eliminating the antilipolytic adenosine A1 receptor does not lead to compensatory changes of PGE2 or nicotinic acid effects on lipolysis. Acta Physiol 2007; 190(1): 87-96.

[9] Fredholm BB, Irenius E, Kull B, Schulte G. Comparison of the potency of adenosine as an agonist at human adenosine receptors expressed in Chinese hamster ovary cells. Biochem Pharmacol 2001; 61(4): 443-8.

[10] Schulte G, Fredholm BB. Human adenosine A(1), A(2A), A(2B), and $A(3)$ receptors expressed in Chinese hamster ovary cells all mediate the phosphorylation of extracellular-regulated kinase $1 / 2$. Mol Pharmacol 2000; 58(3): 477-82.

[11] Schulte G, Fredholm BB. The G(s)-coupled adenosine A(2B) receptor recruits divergent pathways to regulate ERK1/2 and p38. Exp Cell Res 2003; 290(1): 168-76.

[12] King AE, Ackley MA, Cass CE, Young JD, Baldwin SA. Nucleoside transporters: from scavengers to novel therapeutic targets. Trends Pharmacol Sci 2006; 27(8): 416-25.

[13] Löffler M, Morote-Garcia JC, Eltzschig SA, Coe IR, Eltzschig HK. Physiological roles of vascular nucleoside transporters. Arterioscler Thromb Vasc Biol 2007; 27(5): 1004-13.

[14] Ballarín M, Fredholm BB, Ambrosio S, Mahy N. Extracellular levels of adenosine and its metabolites in the striatum of awake rats: inhibition of uptake and metabolism. Acta Physiol Scand 1991; 142(1): 97-103.

[15] Barnes K, Dobrzynski H, Foppolo S, et al. Distribution and functional characterization of equilibrative nucleoside transporter-4, a novel cardiac adenosine transporter activated at acidic $\mathrm{pH}$. Circ Res 2006; 99(5): 510-9.

[16] Berne RM. Cardiac nucleotides in hypoxia: possible role in regulation of coronary blood flow. Am J Physiol 1963; 204: 317-22.

[17] Gerlach E, Deuticke B, Dreisbach RH. Der nucleotid-abbau im herzmuskel bei sauerstoffmangel und seine mögliche bedeutung für die coronardurchblutung. Naturwissenschaften 1963; 50: 228-9.

[18] Burnstock G. Historical review: ATP as a neurotransmitter. Trends Pharmacol Sci 2006; 27(3): 166-76.
[19] Fredholm BB, Fried G, Hedqvist P. Origin of adenosine released from rat vas deferens by nerve stimulation. Eur J Pharmacol 1982; 79(3-4): 233-43.

[20] Okada SF, Nicholas RA, Kreda SM, Lazarowski ER, Boucher RC. Physiological regulation of ATP release at the apical surface of human airway epithelia. J Biol Chem 2006; 281(32): 22992-3002.

[21] MacDonald PE, Braun M, Galvanovskis J, Rorsman P. Release of small transmitters through kiss-and-run fusion pores in rat pancreatic beta cells. Cell Metab 2006; 4(4): 283-90.

[22] He L, Wu LG. The debate on the kiss-and-run fusion at synapses. Trends Neurosci 2007; 30(9): 447-55.

[23] Zhang Q, Li Y, Tsien RW. The dynamic control of kiss-and-run and vesicular reuse probed with single nanoparticles. Science 2009; 323(5920): 1448-53.

[24] Spray DC, Ye ZC, Ransom BR. Functional connexin "hemichannels": a critical appraisal. Glia 2006; 54(7): 758-73.

[25] Dale N. Dynamic ATP signalling and neural development. J Physiol 2008; 586(10): 2429-36.

[26] Rackauskas M, Verselis VK, Bukauskas FF. Permeability of homotypic and heterotypic gap junction channels formed of cardiac connexins mCx30.2, Cx40, Cx43, and Cx45. Am J Physiol Heart Circ Physiol 2007; 293(3): H1729-36.

[27] Wong CW, Christen T, Roth I, et al. Connexin37 protects against atherosclerosis by regulating monocyte adhesion. Nat Med 2006; 12(8): 950-4.

[28] Schulz R, Heusch G. Connexin43 and ischemic preconditioning. Adv Cardiol 2006; 42: 213-27.

[29] Lazarowski ER, Boucher RC, Harden TK. Mechanisms of release of nucleotides and integration of their action as P2X- and P2Yreceptor activating molecules. Mol Pharmacol 2003; 64(4): 785-95.

[30] Zhang Z, Chen G, Zhou W, et al. Regulated ATP release from astrocytes through lysosome exocytosis. Nat Cell Biol 2007; 9(8): 945-53.

[31] Robson SC, Wu Y, Sun X, Knosalla C, Dwyer K, Enjyoji K. Ectonucleotidases of CD39 family modulate vascular inflammation and thrombosis in transplantation. Semin Thromb Hemost 2005; 31(2): 217-33.

[32] Picher M, Burch LH, Hirsh AJ, Spychala J, Boucher RC. Ecto 5'nucleotidase and nonspecific alkaline phosphatase. Two AMPhydrolyzing ectoenzymes with distinct roles in human airways. J Biol Chem 2003; 278(15): 13468-79.

[33] Fredholm BB, Sollevi A. The release of adenosine and inosine from canine subcutaneous adipose tissue by nerve stimulation and noradrenaline. J Physiol 1981; 313: 351-67.

[34] Zetterström T, Vernet L, Ungerstedt U, Tossman U, Jonzon B, Fredholm BB. Purine levels in the intact rat brain. Studies with an implanted perfused hollow fibre. Neurosci Lett 1982; 29(2): 111-5.

[35] Lönnroth P, Jansson PA, Fredholm BB, Smith U. Microdialysis of intercellular adenosine concentration in subcutaneous tissue in humans. Am J Physiol 1989; 256(2 PT 1): E250-5.

[36] Andiné P, Rudolphi KA, Fredholm BB, Hagberg H. Effect of propentofylline (HWA 285) on extracellular purines and excitatory amino acids in CA1 of rat hippocampus during transient ischaemia. Br J Pharmacol 1990; 100(4): 814-8.

[37] Conlay LA, Conant JA, deBros F, Wurtman R. Caffeine alters plasma adenosine levels. Nature 1997; 389: 136.

[38] Pedata F, Corsi C, Melani A, Bordoni F, Latini S. Adenosine extracellular brain concentrations and role of $\mathrm{A} 2 \mathrm{~A}$ receptors in ischemia. Ann N Y Acad Sci 2001; 939: 74-84.

[39] Dux E, Fastbom J, Ungerstedt U, Rudolphi K, Fredholm BB. Protective effect of adenosine and a novel xanthine derivative propentofylline on the cell damage after bilateral carotid occlusion in the gerbil hippocampus. Brain Res 1990; 516(2): 248-56.

[40] Müller CE. Medicinal chemistry of adenosine A3 receptor ligands. Curr Top Med Chem 2003; 3(4): 445-62.

[41] Jacobson KA, Gao ZG. Adenosine receptors as therapeutic targets. Nat Rev Drug Discov 2006; 5(3): 247-64.

[42] Akkari R, Burbiel JC, Hockemeyer J, Müller CE. Recent progress in the development of adenosine receptor ligands as antiinflammatory drugs. Curr Top Med Chem 2006; 6(13): 1375-99.

[43] Jacobson KA. Introduction to adenosine receptors as therapeutic targets. Handb Exp Pharmacol 2009; 193: 1-24.

[44] Kiesman WF, Elzein E, Zablocki J. A1 adenosine receptor antagonists, agonists, and allosteric enhancers. Handb Exp Pharmacol 2009; 193: 25-58. 
[45] Cristalli G, Müller CE, Volpini R. Recent developments in adenosine A2A receptor ligands. Handb Exp Pharmacol 2009; 193: 5998.

[46] Kalla RV, Zablocki J, Tabrizi MA, Baraldi PG. Recent developments in A2B adenosine receptor ligands. Handb Exp Pharmacol 2009; 193: 99-122.

[47] Jacobson KA, Klutz AM, Tosh DK, Ivanov AA, Preti D, Baraldi PG. Medicinal chemistry of the A3 adenosine receptor: agonists, antagonists, and receptor engineering. Handb Exp Pharmacol 2009; 193: $123-59$

[48] Fredholm BB, Bättig K, Holmén J, Nehlig A, Zvartau EE. Actions of caffeine in the brain with special reference to factors that contribute to its widespread use. Pharmacol Rev 1999; 51(1): 83-133.

[49] Ledent C, Vaugeois JM, Schiffmann SN, et al. Aggressiveness, hypoalgesia and high blood pressure in mice lacking the adenosine A2A receptor. Nature 1997; 388: 674-8.

[50] Salvatore CA, Tilley SL, Latour AM, Fletcher DS, Koller BH, Jacobson MA. Disruption of the A(3) adenosine receptor gene in mice and its effect on stimulated inflammatory cells. J Biol Chem 2000; 275(6): 4429-34.

[51] Sun D, Samuelson LC, Yang T, et al. Mediation of tubuloglomerular feedback by adenosine: evidence from mice lacking adenosine 1 receptors. Proc Natl Acad Sci USA 2001; 98(17): 9983-8.

[52] Yaar R, Jones MR, Chen JF, Ravid K. Animal models for the study of adenosine receptor function. J Cell Physiol 2005; 202(1): 9-20.

[53] Popescu FD, Popescu F. A review of antisense therapeutic interventions for molecular biological targets in asthma. Biologics 2007; 1(3): 271-83.

[54] Brown R, Ollerstam A, Johansson B, et al. Abolished tubuloglomerular feedback and increased plasma renin in adenosine A1 receptor-deficient mice. Am J Physiol Regul Integr Comp Physiol 2001; 281(5): R1362-7.

[55] Johansson S, Lindgren E, Yang J-N, Herling AW, Fredholm BB. Adenosine A1 receptors regulate lipolysis and lipogenesis in mouse adipose tissue - interactions with insulin. Eur J Pharmacol 2008; 597: 92-101.

[56] Johansson S, Salehi A, Sundström M, et al. A1 receptor deficiency causes increased insulin and glucagon secretion in mice. Biochem Pharmacol 2007; 74(11): 1628-35.

[57] Yang J-N, Tiselius C, Daré E, Johansson B, Valen G, Fredholm BB. Sex differences in mouse heart rate and body temperature and in their regulation by adenosine A1 receptors. Acta Physiol 2007; 190(1): 63-75.

[58] Stenberg D, Litonius E, Halldner L, Johansson B, Fredholm BB, Porkka-Heiskanen T. Sleep and its homeostatic regulation in mice lacking the adenosine A1 receptor. J Sleep Res 2003; 12(4): 28390.

[59] Oishi Y, Huang Z-L, Fredholm BB, Urade Y, Hayaishi O. Adenosine in the tuberomamillary nucleus suppresses the histaminergic system via A1 receptors and promotes non-rapid eye movement sleep. Proc Natl Acad Sci USA 2008; 105: 19992-7.

[60] Wu WP, Hao JX, Halldner L, et al. Increased nociceptive response in mice lacking the adenosine A1 receptor. Pain 2005; 113(3): 395404.

[61] Lankford AR, Yang J-N, Rose'Meyer R, et al. Effect of modulating cardiac A1 adenosine receptor expression on protection with ischemic preconditioning. Am J Physiol 2006; 290: H1469-73.

[62] Huang Z-L, Qu W-M, Eguchi N, et al. Adenosine $\mathrm{A}_{2 \mathrm{~A}}$, but not $\mathrm{A}_{1}$, receptors mediate the arousal effect of caffeine. Nat Neurosci 2005; 8(7): 858-9.
[63] El Yacoubi M, Ledent C, Menard JF, Parmentier M, Costentin J, Vaugeois JM. The stimulant effects of caffeine on locomotor behaviour in mice are mediated through its blockade of adenosine A(2A) receptors. Br J Pharmacol 2000; 129(7): 1465-73.

[64] Chen JF, Beilstein M, Xu YH, et al. Selective attenuation of psychostimulant-induced behavioral responses in mice lacking $\mathrm{A}(2 \mathrm{~A})$ adenosine receptors. Neuroscience 2000; 97(1): 195-204.

[65] Chen JF, Xu K, Petzer JP, et al. Neuroprotection by caffeine and $\mathrm{A}(2 \mathrm{~A})$ adenosine receptor inactivation in a model of Parkinson's disease. J Neurosci 2001; 21(10): RC143.

[66] Chen JF, Huang Z, Ma J, et al. A(2A) adenosine receptor deficiency attenuates brain injury induced by transient focal ischemia in mice. J Neurosci 1999; 19(21): 9192-200.

[67] Chen JF, Sonsalla PK, Pedata F, et al. Adenosine A2A receptors and brain injury: broad spectrum of neuroprotection, multifaceted actions and "fine tuning" modulation. Prog Neurobiol 2007; 83(5): 310-31.

[68] Ohta A, Sitkovsky M. Role of G-protein-coupled adenosine receptors in downregulation of inflammation and protection from tissue damage. Nature 2001; 414(6866): 916-20.

[69] Lappas CM, Rieger JM, Linden J. A2A adenosine receptor induction inhibits IFN-gamma production in murine CD4+ T cells. J Immunol 2005; 174(2): 1073-80.

[70] Ohta A, Lukashev D, Jackson E, Fredholm BB, Sitkovsky M. 1,3,7-trimethylxanthine (Caffeine) may exacerbate acute inflammatory liver injury by weakening the physiological immunosuppressive mechanism. J Immunol 2007; 179: 7431-8.

[71] Montesinos MC, Desai A, Chen JF, et al. Adenosine promotes wound healing and mediates angiogenesis in response to tissue injury via occupancy of A(2A) receptors. Am J Pathol 2002; 160(6): 2009-18.

[72] Yang D, Zhang Y, Nguyen HG, et al. The A2B adenosine receptor protects against inflammation and excessive vascular adhesion. J Clin Invest 2006; 116(7): 1913-23.

[73] Yang D, Koupenova M, McCrann DJ, et al. The A2b adenosine receptor protects against vascular injury. Proc Natl Acad Sci USA 2008; 105(2): 792-6.

[74] Eckle T, Krahn T, Grenz A, et al. Cardioprotection by ecto-5'nucleotidase (CD73) and A2B adenosine receptors. Circulation 2007; 115(12): 1581-90.

[75] Tilley SL, Wagoner VA, Salvatore CA, Jacobson MA, Koller BH. Adenosine and inosine increase cutaneous vasopermeability by activating $\mathrm{A}(3)$ receptors on mast cells. J Clin Invest 2000; 105(3): 361-7.

[76] Hua X, Chason KD, Fredholm BB, Deshpande DA, Penn RB Tilley SL. Adenosine induces airway hyperresponsiveness through activation of A3 receptors on mast cells. J Allergy Clin Immunol 2008; 122(1): 107-13 113.E1-7.

[77] Wu WP, Hao JX, Halldner-Henriksson L, et al. Decreased inflammatory pain due to reduced carrageenan-induced inflammation in mice lacking adenosine A3 receptors. Neuroscience 2002; 114(3): 523-7.

[78] Chen Y, Corriden R, Inoue Y, et al. ATP release guides neutrophil chemotaxis via P2Y2 and A3 receptors. Science 2006; 314(5806): 1792-5.

(C) Bertil B. Fredholm; Licensee Bentham Open.

This is an open access article licensed under the terms of the Creative Commons Attribution Non-Commercial License (http://creativecommons.org/licenses/by-nc/3.0/) which permits unrestricted, non-commercial use, distribution and reproduction in any medium, provided the work is properly cited. 